\title{
Toward understanding the long-term persistence of a local governance system among artisanal fishers in Chile
}

\author{
Jaime A. Aburto $^{1,2,3}$, Wolfgang Stotz ${ }^{1,3,4}$, Georgina Cundill $^{5}$ and Carlos Tapia $^{6}$
}

\begin{abstract}
An important characteristic for the persistence of social-ecological systems (SESs) over time is the adaptation of local institutions to the dynamic of the resources on which they depend, especially when communities face resources with high spatial and temporal variability. Previous studies on Territorial User Rights for Fisheries (TURF) in Chile (Áreas de Manejo y Explotación de Recursos Bentónicos, AMERB) showed that resources with high levels of variability, such as the highly valuable surf clam Mesodesma donacium, can have negative impacts on collective efforts among fishers to govern marine resources under AMERB, resulting in the collapse of local institutions in this boom-and-bust fishery. Here, we reflect on the only known case in Chile (Coquimbo Bay) in which local institutions, its governance mechanisms, and the surf clam $M$. donacium fishery have persisted over long periods of time, despite disturbances from the natural and social systems. Using participatory techniques, we draw on local fishers' in-depth knowledge of both the resource and their own historical coping mechanisms to understand the potential sources of institutional persistence among local fishers faced with a resource that has high levels of variability. We find that this unique success of a surf clam AMERB in Chile is attributed to the local conditions, such as the roots that fishers have to their village, the support by women and family, and also to the ecological settings of Coquimbo Bay and resource characteristics, that facilitate larval dispersal among the different bays, maintaining recruitment and production that sustains the AMERB. Thus, the persistence of the institution has been built over generations of coping with major disturbances to the SES, directly related to the persistence of $M$. donacium stocks over time, which has allowed the development of a well-structured institution with a strong fishers' organization, good leaders, a division of labor among members, shared responsibilities, and equitable income distribution.
\end{abstract}

Key Words: AMERB; co-management; governance; resilience; small-scale fishery; traditional ecological knowledge; TURF

\section{INTRODUCTION}

Various examples of social-ecological systems (SESs) have persisted over time because societies have adapted their institutions to local ecological variability (Janssen et al. 2007). Here, we used the term "institution" to refer to the shared rules, norms, and strategies devised and used repeatedly by humans when interacting with one another and their natural environment (Ostrom 2009). In contexts of high levels of variability, institutions play an important role in supporting societies' capacity to adapt to changes (Armitage et al. 2011). Institutions are therefore an important element of social resilience, which is defined as "the ability of groups or communities to cope with external stresses and disturbances as a result of social, political and environmental change" (Adger 2000). The development of mechanisms and institutions that make it possible to remember past events, implement early warning systems, create buffers against external impacts, and learn to prepare for better future events makes it possible to increase society's resilience (Boyd and Folke 2011). This ability could be crucial for the persistence of local institutions, organizations, or communities, such as smallscale fishers, that rely on and manage highly variable resources (Aburto et al. 2014).

Fisheries, and especially small-scale fisheries, are a classic example of coupled social-ecological systems. Small-scale fisheries are affected both by biological response to oceanographic changes and by socio-economic conditions and market demand, which are expressed from local to global scales (Cline et al. 2017). Accordingly, understanding how local fishery institutions persist over time, how they influence the ability of communities to cope with variability in social and/or ecological dimensions of the SES, and therefore how they contribute toward social resilience in the face of change, is important when designing management strategies and fishery policies.

\section{Challenges for Small-scale Fisheries Management and the Role of Local Ecological Knowledge}

Globally, about 120 million people depend directly or indirectly on small-scale fisheries, and around $95 \%$ of small-scale landings are destined for local consumption (Agapito et al. 2019). However, communities that depend on fisheries for their livelihoods need to cope with high levels of variability, as well as rapid fluctuations in resources over time to sustain their economies and livelihoods (Cline et al. 2017).

Worldwide, the management of small-scale fisheries faces significant challenges despite substantial investment in scientific research, primarily in the natural sciences (Bundy et al. 2008). At the same time, fishers claim that their own expertise has been ignored and that external management interventions can erode some local management as well as customary tenure systems (Aswani 2017).

The incorporation of local ecological knowledge (LEK) into fisheries management provides an opportunity to obtain a better understanding of local ecological processes and their influences on fishing resources (Silvano and Valbo-Jørgensen 2008, Bundy and Davis 2012, Tengö et al. 2014). In contexts where scientific information is poor, fishers' knowledge can be key for small-scale

${ }^{1}$ Universidad Católica del Norte, Facultad de Ciencias del Mar, Departamento de Biología Marina, ${ }^{2}$ Núcleo Milenio ESMOI, ${ }^{3}$ Grupo de Ecología y Manejo de Recursos, ${ }^{4}$ Centro de Estudios Avanzado en Zonas Áridas (CEAZA)., International Development Research Centre, Ottawa, Ontario, Canada, ${ }^{6}$ Centro de Estudios de Sistemas Sociales, CESSO 
fishery management (Berkes et al. 2000, Grant and Berkes 2007, Tesfamichael et al. 2014). Bridging LEK with scientific knowledge is important to enhancing knowledge, practice, and ethics toward sustainability (Tengö et al. 2017). Information about small-scale fisheries is usually not readily available in official records; however, this does not mean that there is no information. This information can be acquired from the memories of resource users, which is a subject gaining increased attention in fisheries research (Tesfamichael et al. 2014). Also, the incorporation of fishers'LEK increases the possibility of local stakeholder participation by engaging fishers in management, environmental education, and monitoring programs (Gerhardinger et al. 2009). The engagement of stakeholders at the local level promotes ecological democracy and positive environmental outcomes (Lipsman 2019). Local ecological knowledge about species is nested within local resource management systems, tools, and techniques, and in the rules and norms (in other words, the institutions) required for effective management and governance (Butler et al. 2012). The integration of LEK and scientific knowledge in resource management could help enhance the resilience of social-ecological systems through increased social resilience, by providing a diversity of knowledge for problem solving and related cross-scale and adaptive governance networks (Butler et al. 2012).

The Small-scale Fishery in Chile and Territorial User Rights for Fisheries (TURFs)

Territorial user rights for fisheries (TURFs) have proven to be successful with Chilean benthic fisheries (known as Áreas de Manejo y Explotación de Recursos Bentónicos, AMERB). Under AMERB, changes were made to the governance and incentives, slowly shifting from top-down centralized control to comanagement (Gelcich et al. 2010). The adoption of the AMERB in Chile was a response to the crisis of the the hard bottom snail Concholepas concholepas fishery (known commonly as "loco"), the most important benthic resource in Chile. Due to the fast recovery of loco stocks in some AMERBs (Gelcich et al. 2010, San Martín et al. 2010), they were intensively promoted by the government and later applied to various other benthic resources (Aburto and Stotz 2013), but without considering the particularities of local fishing communities, their LEK, or the respective biological traits of the resources. Among these other resources is the surf clam Mesodesma donacium ("macha"), which inhabits exposed sandy beaches and is an important species from an economic and ecological perspective for Chilean and Peruvian benthic fisheries (Aburto and Stotz 2013). However, the El Niño (ENSO) events of 1982-1983 and 1997-1998 decimated the surf clam populations from Sechura, Perú $\left(\sim 5^{\circ} \mathrm{S}\right)$ to the central coast of Chile, including Coquimbo $\left(\sim 29^{\circ} 55^{\prime} \mathrm{S}\right)$ leaving some minor populations in between (Riascos et al. 2009, Aburto et al. 2014). The $M$. donacium fishery has shown high variability in its landings over its entire distribution range. Fluctuations in landings are a common feature of surf clam fisheries worldwide (McLachlan et al. 1996), making their sustainability difficult to achieve (Ortega et al. 2012). This variability reflects fluctuations in population size, which is related to highly variable levels of recruitment and mortality (Defeo and Alava 1995, McLachlan et al. 1996).

In Chile, since 1997, most of the surf clam beds have been managed through an AMERB (Aburto et al. 2014). From 1997 to 2015 , in Chile, 29 AMERBs were requested for M. donacium; of these, just three were operating in 2015. Most of the surf clam
AMERBs in Chile have failed due to the lack of recruitment, as has been described for the AMERB Tongoy (Aburto and Stotz 2013, Aburto et al. 2014). The only successful surf clam AMERB, given its history of continuous landings over time, is the AMERB Peñuelas A, located in central-northern Chile (Fig. 1). During 2018, in Chile, $2300 \mathrm{t}$ of $M$. donacium were landed from AMERBs (Servicio Nacional de Pesca y Acuicultura (SERNAPESCA) 2018) of which $975 \mathrm{t}$ corresponded to harvest of Peñuelas A, which shows the importance of this surf clam bed along its distribution range.

Fig. 1. Study zone. (A) The stripped zone shows the regional location of the Coquimbo Bay System (CBS). (B) Coquimbo Bays System (CBS). The black arrows show the sandy beaches in which surf clams have been harvested. (C) Coquimbo Bay. The striped polygon represents the AMERB Peñuelas A, and the gray polygon shows the additional portion of the surf clam population distribution before the 1997-1998 flood. Black dots represent the location of the different coves/fishing communities involved in the surf clam fishery in the AMERB Peñuelas A.
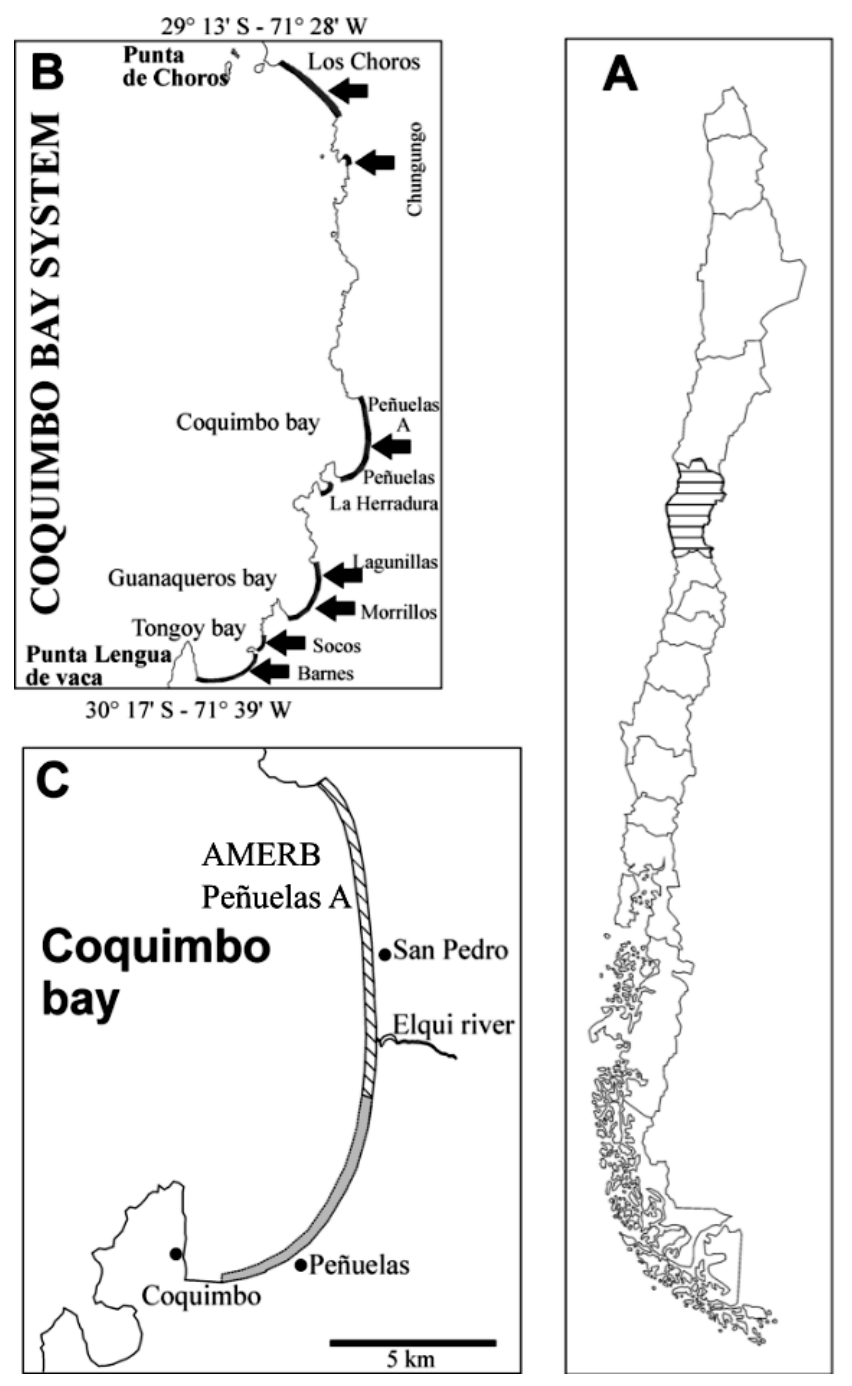
The objective of this research was, therefore, to deepen our understanding of the potential sources of persistence of the surf clam fishery over time in the AMERB Peñuelas A, including the persistence of one of the institutions governing this resource. Drawing on local fishers' in-depth knowledge of both the surf clam and their own historical coping mechanisms, we explore the only known case in which a local surf clam fishery and the fishers' institution have persisted over long periods of time.

\section{Study Area and Brief Introduction to the Social-ecological System of the Surf Clam Fishery in the Coquimbo Bay}

Coquimbo Bay is part of a larger ecosystem, that researchers called "Coquimbo Bays System" (CBS) (Thiel et al. 2007, Flores and Mujica 2009, Mujica et al. 2014; Fig. 1) because a series of five bays occur over $100 \mathrm{~km}$ of shoreline: two in Tongoy (Barnes and Socos bays), Guanaqueros, La Herradura, and Coquimbo. The CBS is bound to the north by the Choros and Damas Islands ( 29 $\left.{ }^{\circ} 17^{\prime} \mathrm{S}\right)$ and to the south by Punta Lengua de Vaca $\left(31^{\circ} 14^{\prime} \mathrm{S}\right)$ (Fig. 1B). The CBS includes several sandy beaches (Fig. 1B) where surf clam harvests have been registered since 1985, when official landings started to be recorded at the local level. Six surf clam AMERBs have been requested by different fisher organizations on three beaches in the CBS. However, only in Penuelas A AMERB, located in Coquimbo Bay (Fig. 1C), has the fishery been permanently operating and reporting landings except for a short period of no landings after the El Niño event of 1997-1998 (Fig. 2A). Since 2001, the surf clam fishery in the AMERB Peñuelas A has been operational. Since the 2015 tsunami, landings have shown a continuous decline. In addition to the tsunami, in the last 5 years, the increasing number of surges affecting the coast have affected the fishery, making it difficult for surf clam fishers to work in the swell area. Despite this, the stock has remained relatively stable since 2013 , even showing an increase in biomass from 2017 onward (Fig. 2B).

Three different groups of fishers are involved in the surf clam fishery of Peñuelas A AMERB: hand gatherers from the San Pedro Guild Association and divers from Peñuelas and Coquimbo coves (Fig. 1C). Hand gatherers harvest the resource from the beach, entering the surf zone during low tides and working at a depth of ca. $1-1.5 \mathrm{~m}$ in the breakers closest to the beach. Hand gatherers and divers use different portions of the surf clam bed, as divers work deeper than do hand gatherers (Fig. 3).

The most traditional surf clam fishers in Coquimbo Bay are the hand gatherers from the San Pedro fishing community. However, at the beginning of the AMERB process, the hand gatherers of San Pedro were excluded from the AMERB Peñuelas A, and the fishing rights were granted to divers of Peñuelas cove. After a period of conflict, this situation was regularized by internal agreements between the different groups of fishers, beyond the legal aspects that govern the AMERB at the national level. At present, the fishery is developed by the three fishers' organizations. Although the organization of Peñuelas is in charge of the AMERB, the three organizations carry out the harvest in a coordinated manner. A technical consultant and a catch quota are requirements in the national AMERB policy. The technical consultant carries out a direct assessment of the surf clam bed once a year, in a collaborative effort with the fishers. Based on the results of direct assessments, an estimate of catch quota is made and reported to the Undersecretary of Fisheries for its approval.
As part of their internal coordination, the organizations have decided that the annual quota will be divided among the organizations. Each organization administers its quota independently and makes its own marketing arrangements.

Fig. 2. (A) Landings of surf clams at Coquimbo Bay. The periods of open access and AMERB are shown. (B) Number of surf clam individuals (blue) and total biomass (red) estimated in the AMERB Peñuelas A during the AMERB governance period (from 2000 to the present).

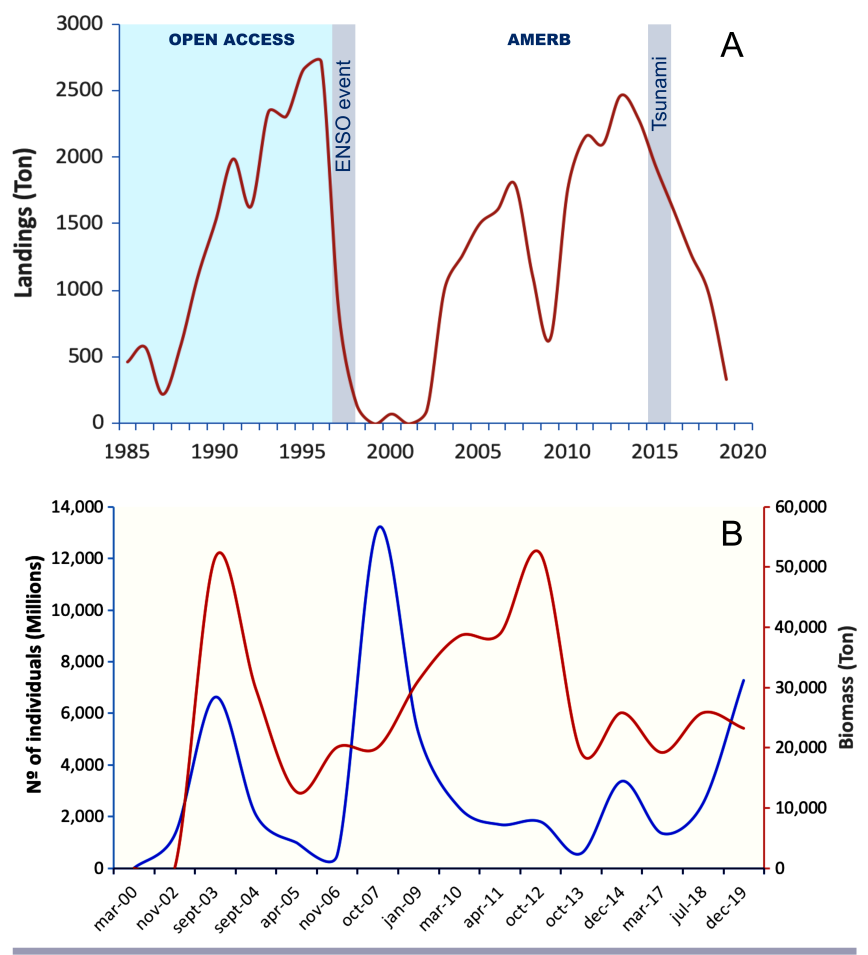

Fig. 3. (A) Harvesting zones of divers and hand gatherers along the shore. (B) and (C) surf clam divers. (D) and (E) hand gatherers.

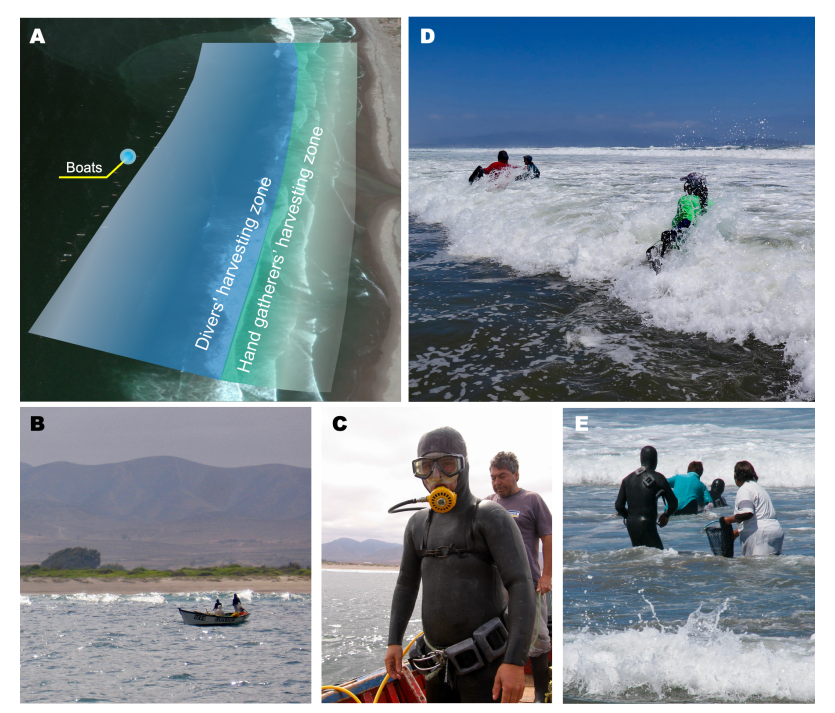


The focus of this study is on the hand gatherers from the San Pedro fishing community. This community was selected because of their long history and high level of dependence on the surf clam fishery and the persistence that the institution and its fishery have shown over time.

\section{METHODS}

To uncover how hand gatherers from San Pedro understand the persistence of the institution and the surf clam fishery over time, we held two workshops with a group of fishers to harness their LEK, based on historical timelines and participatory causal dynamic techniques (Fig. 4) (Chevalier and Buckles 2008). The same group of fishers (10) participated in both workshops. The participants were leaders of the San Pedro Guild Association (two people) and fishers belonging to the AMERB (four people) and commercial committees (three people). The leaders and members of the AMERB and commercial committees were elected by members of the San Pedro Guild Association. In this context, they represented the organization. Both committees are made up of five people of which four from each committee participated in the workshops. Also, an elder of the community (ca. 70 years old), who was considered knowledgeable about the functioning of the fishery over time, participated. Although women actively participate in the surf clam fishery and in meetings, only men are formally part of the two committees mentioned earlier and therefore participated in the workshops because they held the institutional memory of changes in the organization over time. The lack of participation of women in this research could however have skewed the results and is a potential limitation of the study.

Fig. 4. Some participants of the workshops and an indication of the process. (A and B) timeline technique. (C and D) causal dynamics technique. (C) some of the fishers assess the influence of factors (pink cards) over other factors (yellow cards). (D) Development of the matrix of Influence/Dependence. Numbers represent the estimated influence of factors in yellow cards over the factors in pink cards $0=$ null influence; $1=$ weak influence; $2=$ medium influence; $3=$ strong influence.

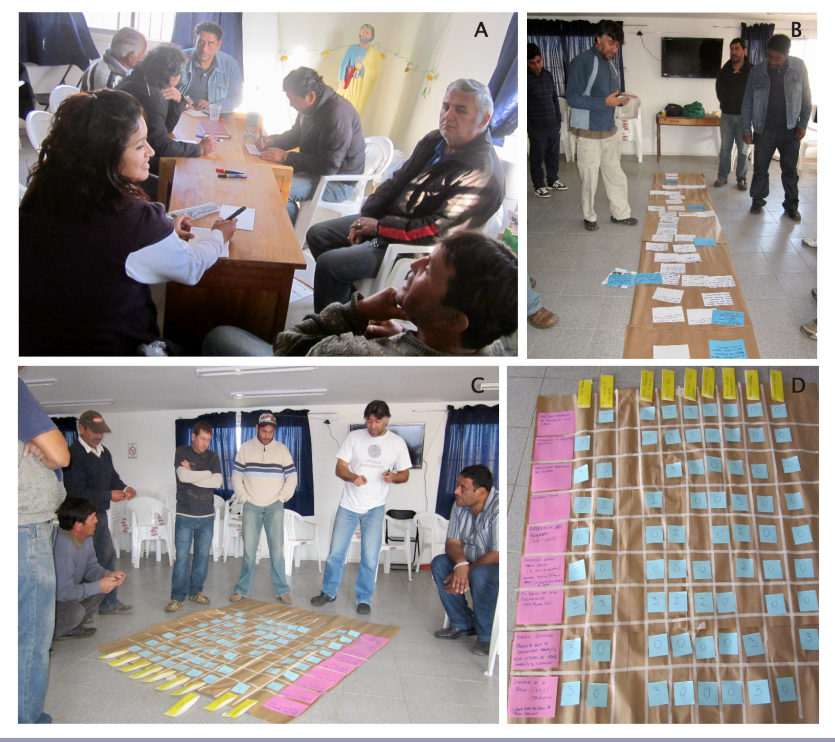

During the first workshop, a participatory timeline was developed (Fig. 4). This technique engages with and explores people's knowledge and perceptions of how a problem or situation has evolved over time, and the changes that occurred in the process (Chambers 1994, Chevalier and Buckles 2008). This technique has been used with other fisher communities in central-northern Chile to analyze their history and their fisheries (Gallardo et al. 2011, Aburto et al. 2013).

For the timeline, two groups were formed, with five people in each group. With the help of facilitators, each group used cards to write down the most important events that had happened in their community related to the surf clam fishery and its governance, as far back as they could remember. Once the events were identified, both groups worked together to order the events chronologically. For the most important events associated with the fishery and the institution, fishers were asked to discuss the positive or negative impact of the event, for the fishery and for local governance.

In the second workshop, we facilitated a brainstorming exercise, in which fishers identified factors that contributed to the persistence of the fishery and the institution over time (Fig. 4). In a subsequent analysis we categorized and grouped the factors into three domains: local governance, biophysical environment, and fishery administration (Table 1). Here, we differentiate the categories of fisheries administration, which includes elements of the AMERB policy, with top-down regulations from the Undersecretary of Fisheries, and of local governance, understood as a set of factors related to collective-choice rules, which are institutions, and associated with self-organization (Ostrom 2009).

To explore how the fishers perceived the interaction between the different factors, in the same workshop, we facilitated an exercise based on the dynamic causal technique (Chevalier and Buckles 2008). This technique helps in assessing the causes of a key problem/situation and the way in which each factor interacts with and influences others (Chevalier and Buckles 2008). The dynamic causal technique relates factors in a double-entry matrix. In it, participants assessed the influence of each factor in a row on the other factors arranged in a column (Fig. 4). For the analysis, we asked fishers to consider three levels of influence: weak (1), medium (2), and strong (3). If the fishers considered that there was no influence of one factor over another, then we used a zero value (0). Thus, each value between 1 to 3 in each of the cells of the matrix represents the influence of a factor in row $X_{(i . . . n)}$ on each factor in column $\mathrm{Y}_{(\mathrm{i} . . . \mathrm{n})}$ (Fig. 4). The factors were defined in neutral terms, as what should be determined at this stage are the direct influence relationships between factors, and not their state. Such a technique has been used successfully for the participatory design of management plans and to facilitate decision-making processes or explore alternatives for local governance in diverse small-scale fisheries in Chile (González et al. 2002, Tapia et al. 2002, Aburto et al. 2017).

The causal dynamic technique allows for the participatory graphic representation of the results and the interactions between the factors based on the sum of the influences and dependencies calculated from the influence/dependency matrix. However, in order to avoid the workshop taking too long, we used software to generate the graphic representation of the results during the workshop itself. Based on the same matrix of influence/ 
Table 1. Factors identified in the workshop with fishers. Twenty factors were identified and grouped into three domains: fishery administration, biophysical, and local governance.

\begin{tabular}{|c|c|c|}
\hline Group & Variable & Description \\
\hline \multirow[t]{4}{*}{$\begin{array}{l}\text { Fishery } \\
\text { Administration }\end{array}$} & Technical advice & $\begin{array}{l}\text { The AMERB policy requires technical advice for the resource administration. With direct } \\
\text { assessment, it is possible to harvest the resource based on quota estimation. }\end{array}$ \\
\hline & Fisheries regulation & $\begin{array}{l}\text { The fisheries regulation or fisheries law changed the traditional ways in which the resource was } \\
\text { exploited and did not allow migration. However, these regulations have a positive outcome because it } \\
\text { is possible to exclude poachers. }\end{array}$ \\
\hline & Enforcement & The AMERB policy allows enforcement against poachers. \\
\hline & Illegal fishery & $\begin{array}{l}\text { The poaching of resources requires more organized fishers to protect their resource. Also, to protect } \\
\text { resources, they know that they must be in the village. For this reason, poaching also influences their } \\
\text { migrations. Now they cannot migrate. }\end{array}$ \\
\hline \multirow[t]{5}{*}{ Biophysical } & Inflow water & $\begin{array}{l}\text { According to LEK, the presence of rivers and estuaries favors the growth of surf clams because of } \\
\text { the contribution of nutrients. Also, some scientific studies report the presence of juveniles and } \\
\text { recruits near the river mouth. However, a negative aspect is the river may flood and kill the resources } \\
\text { because of mud. Contamination events are also a negative aspect of the river inflow. }\end{array}$ \\
\hline & Permanent resource & $\begin{array}{l}\text { The presence of the surf clam on the beach is permanent. Fishers remember that the resource } \\
\text { disappeared only in 1997-1998. However, the resource recovery was fast. }\end{array}$ \\
\hline & Bay shape & $\begin{array}{l}\text { According to the fishers, the bay shape and its orientation determine whether the bay will receive } \\
\text { "food" ("aguajes") or rich water from other places, such as a sink bay. The shape provides high } \\
\text { retention capacity and allows the permanence of food in the bay. Also, they mentioned that the bay } \\
\text { shape determines the kind of activity that can be done. They referred, for instance, to other bays that } \\
\text { are more closed and allow aquaculture activities or the presence of a pier that allows boats to } \\
\text { perform other kinds of activities/fisheries. }\end{array}$ \\
\hline & Beach dynamic & $\begin{array}{l}\text { Refers to the kind of waves and sand. According to the fishers, in Coquimbo bay, it is possible to } \\
\text { find all the different kinds of beaches on which the surf clam can inhabit. The kind of beach defines } \\
\text { the waves and the grain size of the sand. }\end{array}$ \\
\hline & Bay connectivity & Refers to the connectivity with other surf clam beaches in the surrounding areas. \\
\hline \multirow[t]{11}{*}{ Local Governance } & Surf clam hand gatherers & $\begin{array}{l}\text { The only activity that they have in fishery or in their livelihood is to be surf clam hand gatherers: } \\
\text { They depend exclusively on the surf clam. For this reason, when the resource abundance decreased, } \\
\text { they migrated along the coast looking for more productive beds. }\end{array}$ \\
\hline & $\begin{array}{l}\text { Traditional ecological } \\
\text { knowledge }\end{array}$ & $\begin{array}{l}\text { As they are exclusively surf clam fishers and given that they have migrated along the coast and to } \\
\text { different kinds of beaches, they recognize that they have a lot of knowledge about the resource and } \\
\text { its dynamics }\end{array}$ \\
\hline & Migrations & $\begin{array}{l}\text { In the past, they migrated along the coast. They migrated when the resource abundance decreased or } \\
\text { when they looked for better resource quality (largest sizes). Fishers said that with migrations they } \\
\text { "let the surf clam bed rest." Also, they said that migration was part of their traditions. They liked } \\
\text { migrations and to stay far from home, camping on other beaches, etc. }\end{array}$ \\
\hline & Territorial identity & They have deep roots with their caleta/villages. \\
\hline & Presence of women/family & $\begin{array}{l}\text { Women have been present throughout the history of the village and fishery. The presence of women } \\
\text { in the present organization has helped to reduce conflicts and provide better organization. In the } \\
\text { past, the presence of women and the family conditioned those that migrated to return to the village. }\end{array}$ \\
\hline & Fishing technique & $\begin{array}{l}\text { They had changed the way resources were harvested. They tried different fishing techniques and } \\
\text { avoided those that produced more damage to the resource. Now, they exclusively used their hands for } \\
\text { the resource harvest }\end{array}$ \\
\hline & Agreement compliance & $\begin{array}{l}\text { The agreement compliance indicates that at the present, they are more organized fishers and all of } \\
\text { the agreements (inside the local institution and also external agreement) are fulfilled by the members } \\
\text { of the organization. }\end{array}$ \\
\hline & Committees' work & $\begin{array}{l}\text { There are six committees in the organization, and all of the work of the organization is based on the } \\
\text { decisions of those committees. }\end{array}$ \\
\hline & Organized fishers & $\begin{array}{l}\text { Since 1997-1998, when the resource collapsed and they lost the area, they have worked as an } \\
\text { organization with strong collective action. These experiences allowed them to understand the } \\
\text { importance of work as organized fishers. }\end{array}$ \\
\hline & Presence of young people & $\begin{array}{l}\text { Refers to the presence of young people with more scholarship in the organization. This allows a new } \\
\text { vision and a new way of relationships inside the organization. }\end{array}$ \\
\hline & Good leaders & $\begin{array}{l}\text { Since they are working as an organization, a group of strong and young leaders learned how to work } \\
\text { with the organization. Currently, the local chair has representation at regional and national levels. } \\
\text { This has allowed an increase in social capital with new and strong networks for the organization. }\end{array}$ \\
\hline
\end{tabular}

dependence built by the fishers (Fig. 4), we used the open access software MICMAC (Cross-Impact Matrices, Multiplication Applied to Classification, Lipsor Laboratories; http://es. laprospective.fr) to represent the results of the causal dynamics techniques graphically and to conduct a structural analysis (Godet and Durance 2011). The graphical results of the causal dynamic were presented and validated in the same workshop with the fishers.

MICMAC's data analysis is based on the properties of Boolean matrices, allowing for the identification of indirect influences between factors. MICMAC enables the calculation of the direct influences and the strength of the influence between two variables, 
as well as the indirect influence through a third variable. MICMAC performs successive iterations of the matrix until it reaches stability. These iterations allow for the emergence of indirect influences and feedback processes between variables. Based on the relationships between variables, the software identifies five levels of influence: extremely weak, weak, moderate, strong, and very strong.

The MICMAC software allows for the analysis of interactions between groups of factors. In this case, we used it to analyze how factors from the three identified domains-local, biophysical environment, and fishery administration-interact. We conducted this analysis to determine the relative importance of each domain in the social-ecological system analyzed, based on the sum of the individual influences of the variables belonging to each defined domain.

To analyze the importance of each domain, we estimated a total influence and dependence of each one. Similar to what we described previously for the causal dynamic technique, a double entrance matrix was developed to estimate the influence of each domain over the others; this influence was the result of the sum of influences of all factors of one domain over the other domain. Because each domain has different numbers of factors, we standardized the total influence of each domain in the system by dividing the total influence by the number of variables in the domain. Finally, we estimated for each domain, the proportion of its average influence on the total system.

\section{RESULTS}

\section{The Development of the San Pedro's Fishers' Institution over Time}

In San Pedro, the whole community has developed around the surf clam fishery. The San Pedro fishers' local knowledge, as expressed in the timeline, showed a long tradition associated with the surf clam fishery (Fig. 5). According to the oldest person in the group (ca. 70 years old), members of his family have been involved in the surf clam fishery since the early 1900 s.

Based on the results of the historical timeline, three key categories emerged, under which we classified the results: changes in fishing methods, migrations, and the impacts of AMERB on local governance.

\section{Changes in Fishing Methods}

Fishers highlighted a series of changes in the fishing methods, some of which are related to techniques or equipment that have improved the working conditions, such as the use of wetsuits and masks introduced from 1966 onward (Fig. 5). Other changes relate to modifications that cause less injury to the resource, for example, reducing the breakage of surf clam shells. In relation to this, fishers highlighted two changes in the harvesting system. The first was the abandonment of trawling (in 1978) given its negative effects on the resource. For trawling, fishers used a mesh bag with an iron ring in its mouth. The iron ring was buried in the sand and then trawled to collect the surf clams.

The second change in harvesting techniques was the implementation, in 1989, of the use of two hands to remove surf clams (Fig. 5). Before 1989, the hand gatherers harvested the surf clam by moving their feet until they felt the surf clam in the loose ground. Then, they picked it up by hand. However, the fishers
Fig. 5. Timeline developed with hand gatherers of San Pedro during the workshop, showing positive and negative changes over time. Elements of local governance (yellow), fishery (red), and migrations (green) were identified.

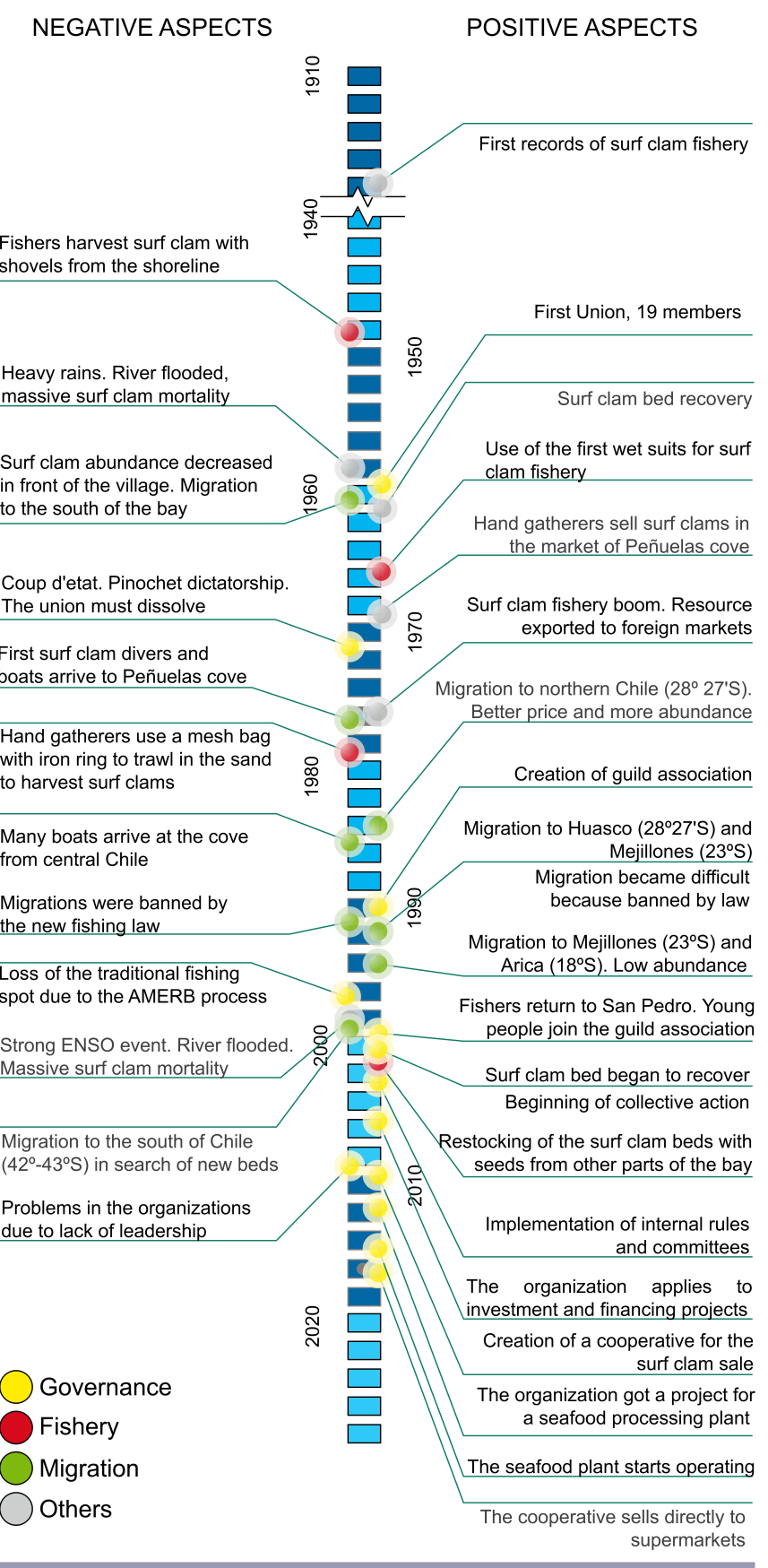

changed this approach because their feet broke the shell; the broken surf clam decomposed faster after the harvest, causing problems with the sale of the product. At present, fishers catch the surf clam by using their feet to make a small hole in the sand; then, to loosen the sand, they quickly move their hands in circular motions on the bottom. Women still harvest the resource by using their feet to loosen the ground; however, they are considered more 
careful than men when using this approach. All these changes in the way in which the resource is extracted reflect a learning process of fishers that seeks to inflict less damage to the resource.

According to the fishers, an important negative impact on fishery sustainability was the arrival, in 1978, of the first boats and surf clam divers from central Chile $\left(\sim 32^{\circ} \mathrm{S}\right)$ (Fig. 5), coincident with a decrease in catches in that region of Chile. This immigration process, which increased from the 1980 s, is perceived as a negative issue for the surf clam bed, given the increase of landings in Coquimbo Bay after that (Fig. 2A).

\section{Migrations}

Fishers mentioned that migrations were a common characteristic of the surf clam fishery and traditionally have been associated with resource variability. San Pedro's fishers remember four massive and long-term migrations since 1989 (Fig. 5). Most of these migrations took place to the north of Chile $\left(\sim 28^{\circ} \mathrm{S}, \sim 23^{\circ} \mathrm{C}\right.$, and $\left.\sim 18^{\circ} \mathrm{S}\right)$. The most important migration, given the number of fishers and the duration, was to the south of Chile in $1998\left(\sim 43^{\circ}\right.$ $\mathrm{S})$, when the resource collapsed in Coquimbo Bay due to the ENSO event (Fig. 2A). Most of the hand-gatherer fishers migrated, although migrations were forbidden by law. Because this group of fishers consisted exclusively of surf clam hand gatherers, its members migrated because they did not have other options.

Fishers acknowledged that the migrations took place each time the fishers perceived a decrease in the resource population level; however, they also highlighted that they enjoy the migrations and perceive it as part of their tradition.

Fishery regulations that ban inter-regional migrations are perceived as negative by fishers, as fishers cannot legally migrate when the resource becomes scarce. An inability to migrate was perceived as negative for the resource, too, as it does not allow the resource to recover.

\section{Local Governance under the AMERB Regime}

Although the AMERB policy produced some problems associated with limiting migrations, fishers recognized that the policy was useful for helping them to formalize and reach a more developed level of organization. Despite different types of organizations previously being operational, fishers recognized that the formation of the Guild Association in 1990 was an important milestone in organizing and grouping the people from the San Pedro community involved in the fishery (Fig. 5). Two situations motivated them to work collectively during the late 1990s. The first was the loss of the surf clam due to a river flood in 1997-1998, associated with the El Niño event at that time. The second was the loss of the right to harvest the surf clam, given the AMERB implementation and its assignment to the Peñuelas cove divers organization. The change to collective action thus occurred in 2000. All these actions and changes in the organization were the results of the learning process from previous experiences.

The inclusion of young people, with higher education levels, is perceived as having a positive impact on the hand gatherers' organization. This allowed for the assigning of some of the guild association's tasks to people with specialized skills, such as administration and accounting. In 2004, the organization began applying for different projects, e.g., infrastructure, that have helped the organization develop. Fishers associated these events with good leadership in the organization.

In the San Pedro guild association, fishery-related tasks have been divided among five committees (AMERB, marketing, discipline, project application, and members' welfare), with strong internal rules that facilitate the organization's functioning. The most important are the AMERB and marketing committees. The AMERB committee regulates the daily quotas, controls the minimum catch size $(60 \mathrm{~mm})$, and designates the patrol shift teams (among other tasks), the latter to avoid poaching by other fishers. The marketing committee sells the resource, negotiates the price, receives the orders the day before the harvest, and communicates the total order to the AMERB committee (among other tasks). This collective form of work has allowed the organization to sell the product. In the past, surf clam hand gatherers sold their harvests individually, without collaboration among themselves. Because they worked alone, they also sold their products to a large number of middlemen, who determined the price of the resource. In contrast, since the surf clam fishers started working collectively, they have been able to collectively determine the price of the resource, thus controlling the market. Each member of the organization earns the same amount of money for the work, independent of each individual's total catch on a day. These changes in the way in which surf clam fishers carry out their activities illustrate the evolution of the fishers' institutional capacity over time.

\section{Local Explanations for the Persistence of the Fishery}

Fishers identified 20 factors that have influenced the success of the fishery and their institution over time (Table 1). We assigned the factors to three different domains: local governance, biophysical, and fishery administration. Factors assigned to the local governance domain are related to the governance of the institution during both the open access and AMERB periods. Factors assigned to the biophysical domain are related to oceanographic, biological, and ecological aspects that fishers highlighted as important to the surf clam fishery and to the persistence of the local institution over time. Factors assigned to the fishery administration domain are directly related to the law/ policy (i.e., "fishery law"); however, others, like "technical advice," do not depend on the fisheries authorities but, rather, are the result of the implementation of the AMERB policy, which led to interactions with scientists to obtain direct assessments of resource stocks. The fishing policy provides the national framework for the AMERBs; however, it was labeled "fishery administration" to differentiate it from "local governance," which does not necessarily have a relationship to the governance provided by the fishing policy. In other words, the day-to-day practices of local governance are, at times, independent of national fishery policies.

\section{Interaction between Elements that Supported Effective \\ Governance}

Four factors have a strong influence on this SES, three of them from the local governance domain and one from the biophysical domain (Fig. 6). The permanent availability of surf clams in the bed ("permanent resource") is the most influential factor and has direct influence on the fisher organization (Fig. 6). The other influencing factors are the LEK that the fishers have about the resource; the roots that fishers have in their village ("territorial 
identity"), which means that each time they migrated, they returned to the village; and the well-developed fishers' organization ("organized fishers") (Fig. 6). The well-developed fishers' organization is highly influential, but also highly dependent on other factors (Fig. 6). The fishers' organization is influenced by factors from the biophysical domain, such as the permanence of the surf clam beds, meaning that the persistence of the institution over time depends on the nature of the ecological system. In other words, the permanence of the resource over time gives stability to the fishers' organization.

Fig. 6. Map of direct influences and dependences of different variables identified by fishers in the workshop. The bubble size is related to their influence on the system (cause index); different colors represent each of three domains. Continuous arrows represent the $10 \%$ with the strongest direct influence, and discontinuous arrows represent the $10 \%$ with the strongest indirect influence. The bubble size represents the qualitative influence degree.

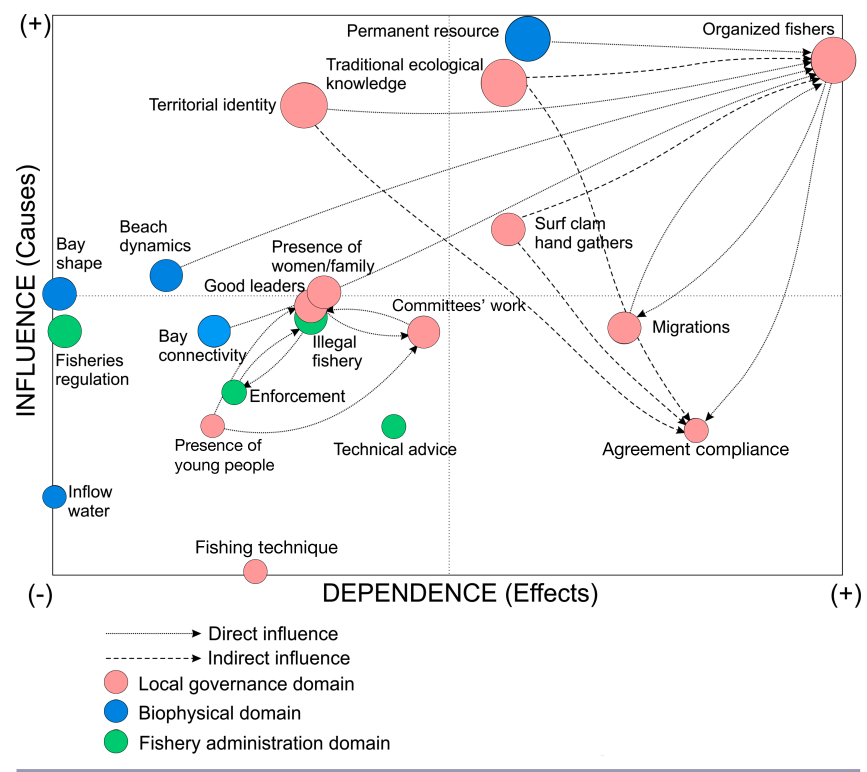

In the center of the direct map are the factors that play a role in system regulation. The system is strongly regulated by five factors (Fig. 6), four of which belong to the local governance domain. The division of the organization's tasks among different committees ("committees'work") is closely related to the presence of a good leader in the organization. Fishers highlighted the importance of the presence of women and/or families, because this contributed to the feeling of having "roots" within the village and motivated the fishers to return after each migration. Poaching ("illegal fishing"), plus the fact that San Pedro's fishers are exclusively surf clam hand gatherers and cannot develop other fishing activities within the area ("surf clam hand gatherers"), have influenced fishers by making them more organized in order to deal with the problem of poaching and improve resource management (Fig. 6).

At the bottom right of the graph are factors with low influence and high dependence (Fig. 6) and that reflect the effect of influential factors. They can be regarded as potential indicators for monitoring changes. That is the case of the organization's compliance with internal agreements ("agreement compliance"), which could be an indicator of the "health" of the fisher organization and the governance. The "agreement compliance" is a direct result of the well-developed fishers' organization but also depends on the indirect interaction with variables that help strengthen the governance, such as the local ecological knowledge (LEK), the roots with the fishing community ("territorial identity"), and the fact that they depend exclusively on the surf clam as hand gatherers ("surf clam hand gatherers") (Fig. 6).

In general, aspects related to fishery administration (Table 1) have medium influence. The persistence of the fishery and the institution resulted mainly from the interaction of factors in the biophysical and local governance domains, such as, e.g., the permanent availability of surf clams in the bed, LEK, territorial identity, and leadership (Fig. 6).

\section{Disentangling the Complex Interactions among Factors in the Different Domains}

Most of the interactions identified from fishers' knowledge are strong and form a complex web of interactions among the factors in the biophysical, fishery administration, and local governance domains. Given the highly complex interactions among the different factors, in this section, we expand the analysis to the $25 \%$ strongest interactions between factors (Fig. 7).

\section{Interaction between the Biophysical and Fishery Administration Domains}

The only interaction between the biophysical and fishery administration domains is the reliable stock of the resource in the bay over time ("permanent resource") and the technical advice for the direct assessment and quota estimation for the resource in the AMERB ("technical advice") (Fig. 7A). According to the fishers, the technical advice keeps the fishery within sustainable exploitation levels (Table 1), which has contributed to the success of this AMERB. The "fisheries regulation" (AMERB policy) provides the right to fish to the fishers' organization. This allows the organization to exclude outsiders from the fishery and request that the fishery authorities enforce the fishery regulations against poachers ("enforcement") (Table 1). This is considered fundamental to the fishery's sustainability.

\section{Interactions between the Fishery Administration and Local Governance Domains}

The fishing law has promoted the organization of fishers through the implementation of the AMERB. Fishers perceive this change to a more organized system as a positive one (Fig. 7B), although at the beginning, when the AMERB was implemented, the fishers perceived it as negative, because they lost access to the surf clams (Table 1; Fig. 5). As the AMERB requires continuous direct assessments, the fishers highlighted a mutual positive interaction between the consultants who conduct the direct assessment (technical advisors) and the fishers' organization (Fig. 7B) given the collaborative work that has been done.

\section{Interaction between the Local Governance and Biophysical Domains}

The "bay shape" and "bay connectivity" (from the biophysical domain) are perceived as having a strong influence over fishers' migrations (from the local governance domain) (Fig. 7C). In relation to the bay shape, the fishers mentioned that Coquimbo 
Fig. 7. Interaction between the variables identified by fishers during the workshop between (A) the fishery administration and biophysical domain, (B) the fishery administration and local governance domain, (C) the local governance and biophysical domain, and (D) the variables from the three domains. Given the high number of interactions, the figures show the $25 \%$ strongest interactions in the system, filtered with MICMAC software.
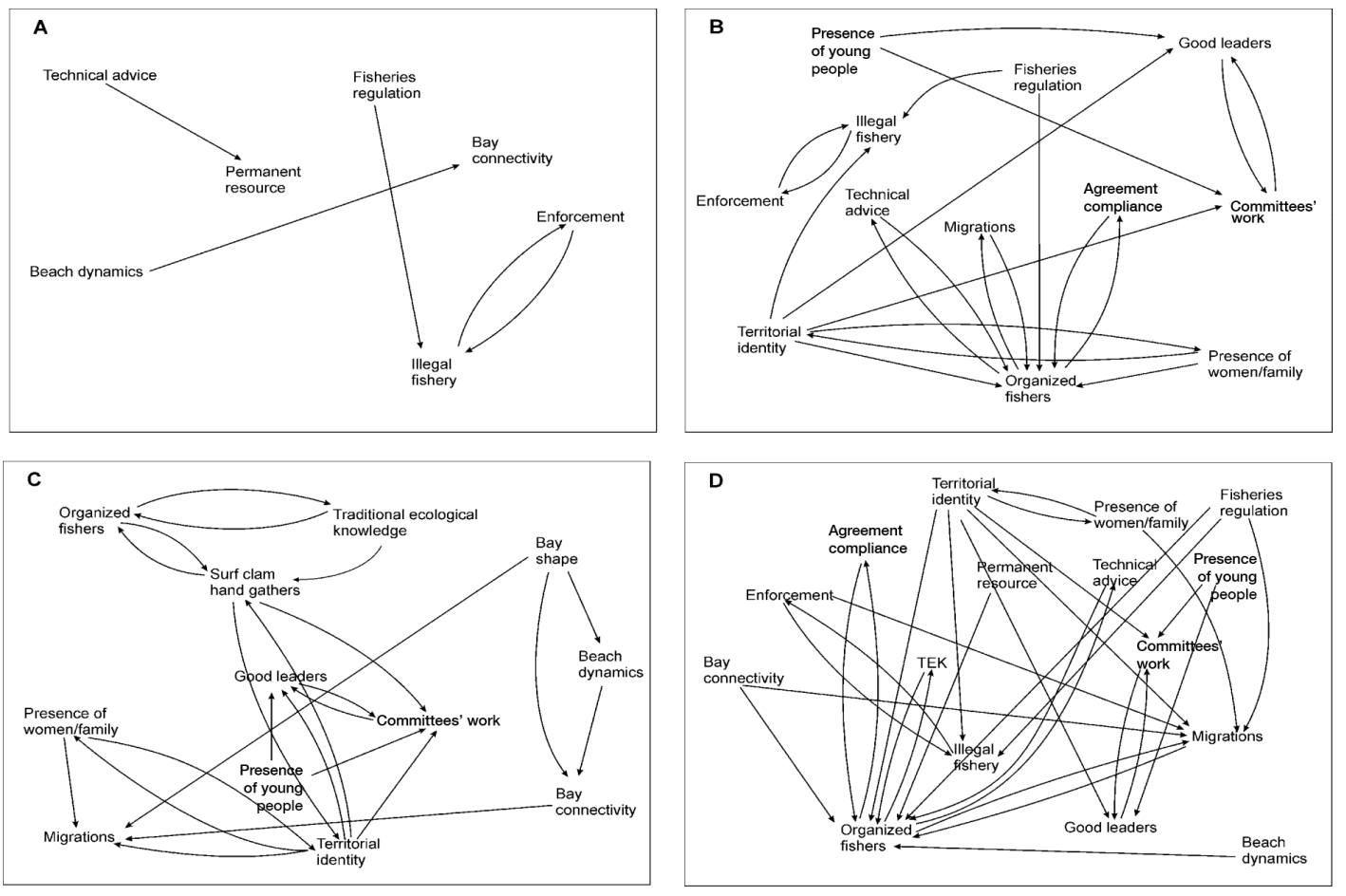

is a closed bay that allows for the retention of phytoplankton-rich waters (known by them as "aguajes") that support high productivity in the bay. They relate the "aguajes" to food for the surf clams (Table 1). However, the fishers highlighted the fact that the bay shape also determines the kind of activity in which they can engage (Table 1). Because it is not possible to have a pier, they are forced to work as hand gatherers. For this reason, when surf clam populations decreased, they migrated to support their livelihood.

The "bay connectivity" refers to the connection with other surrounding beaches, suitable for surf clams. Based on their LEK, fishers know that the surf clams are highly variable and they have seen that the presence of surf clam juveniles or recruitment (and the surf clam population) could be variable over time and between different surrounding beaches. Both variables from the biophysical domain have influenced the fishers' migrations in the past (Fig. 7), with fishers switching among different surf clam locations within the $15 \mathrm{~km}$ of shoreline in Coquimbo Bay when the surf clam population in front of the village decreased, or between different surrounding beaches when the resource biomass decreased in Coquimbo Bay (Fig. 2B).

\section{Interaction among the Three Domains}

Analyzing the interactions between the three domains, it is the biophysical domain that has the greatest influence on the system. Local governance is influenced first by factors in the biophysical domain and then by factors in the fisheries administration (Fig. 8).
Fig. 8. Interaction of the three domains of SES in the surf clam fishery in Coquimbo Bay, according to the fishers' perception. The size of the bubble is related to the relative contribution of each domain in the SES. The arrows represent the direct relation of influence between the domains.

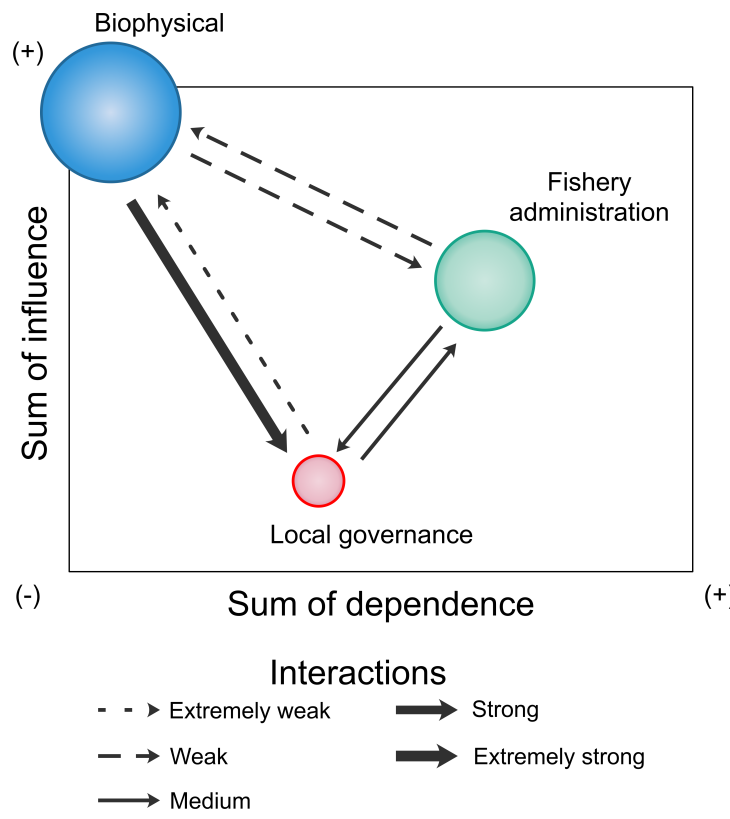


The current well-developed fishers' organization is a consequence of the interaction of factors from the biophysical (three variables), fishery administration (two variables), and local governance (four variables) domains (Fig. 7D). The fishers' organization has been influenced by new variables such as fishery regulations, technical advice and agreement compliance, as well as by traditional variables such as territorial identity, traditional ecological knowledge, and migrations (Fig. 7D). Fishers recognize that the current organization is the result of the evolution of local governance over time, which, in turn, has been favored by elements from the biophysical domain, in particular by the permanent presence of the surf clam over time, because this has allowed for the evolution of the organization over time.

Migration is also influenced by several factors (Fig. 7D). However, at present, fishers recognize more elements that disrupt migration than elements that favor migration (Fig. 5). Fishers agree that, with the fishery regulations and law enforcement, it is not possible to migrate, even if the surf clam population decreases in the bed. Nevertheless, there are some elements from the local governance domain that regulate migrations. In the past, the presence of women and family, as well as the territorial identity, influenced the migrations (Fig. 7D). For example, when the fishers migrated in the past, they always returned to the village (Table 1), although a few fishers settled in other places. At present, the strong and well-developed organization is a positive reason to stay in the village; fishers perceived that the new way of working provided more security and sustainability to the fishery.

\section{DISCUSSION}

The results of this paper, based on fishers' LEK, highlight the importance of the biophysical domain of social-ecological systems in influencing successful and long-lasting fisheries governance. The hand gatherers of San Pedro have developed a well-organized institution, governed by a strong fishers' organization, good leaders, a division of labor within the organization, and functioning in different committees, which implies shared responsibilities. These characteristics are in line with the factors that have been highlighted as key to successful small-scale fisheries co-management: the presence of community leaders, strong social cohesion, a quota system, and communitybased managed areas (Pomeroy et al. 2001, Gutierrez et al. 2011). In our case study, based on fishers' knowledge and analysis, we found that strong leadership and social cohesion are influenced by the biophysical characteristics of the natural domain of SES, rather than purely social factors. In general, managers focus most of their attention on getting the policy right for small-scale fisheries; however, in this particular case and according to fishers, sustainability depends more on local biophysical factors than on the policy, showing that, in some respects, local people feel that nature stewards them. Similar findings have been reported for the Tongoy AMERB, in the CBS, where the surf clam population and its fishery collapsed, resulting in the failure and dissolution of the institution designed for resource management under the AMERB (Aburto et al. 2014).

\section{The Peñuelas A AMERB Success Based on Fishers' Local Ecological Knowledge}

Fluctuating stock is a characteristic of surf clam fisheries. This temporal and spatial variability of the resource makes it difficult to manage (McLachlan et al. 1996, Ortega et al. 2012). This tendency has been also reported in Chile, where most of the surf clam AMERBs have historically failed at some point (Aburto and Stotz 2013, Aburto et al. 2014) and where the Peñuelas A is an exception among the attempts to manage the resource under the AMERB regime. In this study, fishers identified factors based on their own experiences and knowledge that we classified as biophysical conditions of Coquimbo Bay, that seem to favor the presence of a relatively reliable stock, making this AMERB sustainable over time, unlike the other sandy beaches of the CBS or other beaches along the surf clam distribution range (Thiel et al. 2007, Aburto et al. 2014) or even compared with the rocky shore AMERB where $98 \%(n=61)$ of the AMERBs in Coquimbo Region were considered unsustainable $(70 \%)$ or poorly sustainable $(28 \%)$ based on their productivity (Arias and Stotz 2020). In the case of the Peñuelas $A$, the interactions between institutions and the ecological attributes of this SES contribute to success of this fishery (Epstein et al. 2015). A similar case, described for artisanal fisheries in Patos lagoon, Brazil, was an institutional arrangement fit with the ecological setting of the fishery (Kalikoski et al. 2002).

Fishers' LEK highlighted the connection between different surf clam beds in the CBS, which in the past motivated migrations among different surf clam beds in the CBS. This LEK is supported by scientific observation; Olivares (2005) has suggested a metapopulation structure for $M$. donacium within the CBS, meaning that local surf clam populations are connected to other populations by larval dispersion. Two aspects related to the permanence of the resource and the persistence of the institution over time emerge from this observation of fishers. High levels of connectivity may protect ecosystems services from a disturbance and can also facilitate recovery after a disturbance, conferring resilience on the fishery (Dakos et al. 2015). This situation was observed after the El Niño event that caused the collapse of the surf clam bed, where the recovery of the surf clams could be facilitated by the transport of larvae from other sandy beaches within the CBS.

The second aspect is migrations. In this study, we found that migrations occurred before depletion of the surf clam bed and were responses to the natural resource variability. In the past, fishers absorbed this variability by migrating along the same beach, looking for different beds, or among different beaches, looking for more abundant stocks or a larger surf clam size. According to the fishers, migration was a way to let the surf clam bed rest. Ojea et al. (2017) highlighted that shifting between stocks could increase resilience in fisheries, a situation that occurred when fishers migrated within and/or between clam beds. However, different regulations (including the AMERB policy) have eroded this traditional practice, introducing rigidity to this fishery (Aburto et al. 2013) and likely making this fishery less resilient; this could be one of the reasons for the surf clam AMERBs failure. In relation to migrations, interestingly, San Pedro's fishers mentioned that the territorial identity and the roots they have in their village meant that most of them always returned to the cove after a migration. This could be equated with the concept of "sense of place," which is a motivation for stewardship and actions to care for the environment and also mediates how people respond to social-ecological change (Masterson et al. 2017).

Another factor that explains the sustainability of the fishery and the persistence of the surf clam and San Pedro's institution over time, is the high productivity and the retention capacity of the 
Coquimbo Bay. Fishers mentioned that the bay shape and its orientation allows the bay to receive "food" ("aguajes") or water rich in phytoplankton from other places, but also the bay shape provides high retention capacity and allows the permanence of food in the bay. This LEK is supported by scientific research showing that the northern (Choros and Damas island) and southern (Punta Lengua de Vaca) limits of CBS are characterized by upwelling centers, with high primary productivity (Moraga et al. 2001, Thiel et al. 2007). Also, Valle-Levinson and MoragaOpazo, (2006) have suggested that Coquimbo Bay has a counterclockwise gyre, which could favor larval (and phytoplankton) retention inside the bay. These characteristics - the metapopulation structure of $M$. donacium in the CBS, the high primary production, and the larval retention in the bay - could favor the permanent presence of the resource with reliable stock in the AMERB, conditions that contributed to the persistence of the institution and its governance over time.

\section{The Importance of the AMERB Policy to Local Governance in Peñuelas A}

Fishers recognize two advantages of the exclusive exploitation rights given by the AMERB. The first advantage is the possibility of getting technical advice about the stock assessment, monitoring the surf clam bed, and harvesting based on global quotas that are administered within the organizations involved in the fishery. The AMERB has allowed the hand gatherers from San Pedro to develop an equity system in which everyone has the same income, independent of their ability to harvest, their age, or their gender.

The second advantage is the ability to exclude those fishers who do not belong to the AMERB organizations. This is in line with studies about the commons, in which the principles of exclusion and clearly defined boundaries are among the key elements in the success of co-management arrangements (Ostrom 1990, Pomeroy et al. 2001). Ojea et al. (2017) have also suggested that management strategies based on rights-based approaches appear to offer more resilience to fisheries. In line with this, fishers of San Pedro recognized that the AMERB policy helped build a strong institution and therefore contributed toward increased resilience. However, although fishers recognized the importance of the AMERB in strengthening their organization, they also highlighted that this this was strongly influenced by the permanence of the surf clam beds, which allowed the persistence of the institution over time. Fishers recognized that if the surf clam beds had extreme boom and bust cycles, their organization would likely collapse, as has been described previously for the surf clam fishery (Aburto and Stotz 2013, Aburto et al. 2014). The high dependence of this community on a single resource (i.e., the surf clam) is an element that can erode the resilience in this SES. However, fishers have tried to reduce this source of vulnerability through technological innovation, by applying for different projects to build their processing abilities, which produce alternative income for members of the organization.

An important aspect related to the development of the organization involves collective learning processes. The fishers recognize that the collapse of the surf clam bed in the 1997-1998 El Niño, the prohibition to migrate to other surf clam beds, and the loss of the rights to exploit the resource at the beginning of the AMERB, led them to an important change in the way they began to organize themselves. In this regard, Cundill et al. (2015) pointed out that the continuous learning processes and memory of the system are the keys to enhancing resilience.

\section{CONCLUSIONS}

Based on LEK analysis, we identified that this institution has persisted on the basis of a resource that, although variable over time, has remained stable enough not to interrupt the fishery. The characteristics of the biophysical domain and the subsequent implementation of the AMERB have contributed to the persistence of the institution over time and thus increased the resilience of this SES.

The local explanation about the permanence of the resource over time and its effects on the persistence of this institution is that it is a consequence of a series of environmental factors such as bay connectivity, beach dynamics, and the bay's capacity for larval retention (among others). The conclusions based on LEK are also supported by scientific evidence.

The implementation of the AMERB and the loss of fishing rights at the beginning of the process triggered the development of the institution and a mechanism that resulted in a new way of working and organization. Also, as a consequence of learning from negative past events, they have diversified their activity through a processing plant, creating buffers against external shocks, and now are better prepared for future events (see also Boyd and Folke 2011).

The local conditions and ecological setting have strongly influenced the history and tradition of the San Pedro fishing community, including the attachment of fishers to the place, migratory trends, and the evolution of local governance. These are conditions that can be understood through LEK in any setting, prior to the implementation of fisheries regulations such as TURF or co-management regimes, and can be used to improve the design of governance systems and regulations to better fit the local conditions of particular SES.

Responses to this article can be read online at: https://www.ecologyandsociety.org/issues/responses. php/12479

\section{Acknowledgments:}

We are deeply grateful to fishers of San Pedro Cove for their participation in the workshops, especially to Franklin Zepeda for his collaboration. The authors acknowledge the comments and suggestions of the two anonymous reviewers. JAA thanks Paula Guajardo for her help with the design of figures. JAA also thanks support from Conicyt-PAI/Concurso Nacional Inserción en la Academia, Convocatoria 2017-79170078. JAA acknowledges funding for the Research Program in Climate Action Planning by the Concurso de Fortalecimiento al Desarrollo Cientfico de Centros Regionales 2020-R20F0008-CEAZA. 


\section{Data Availability:}

The datalcode that support the findings of this study are available on request from the corresponding author, [JAA]. The datalcode are not publicly available to protect the privacy of fishers that participated in the research.

\section{LITERATURE CITED}

Aburto, J., G. Gallardo, W. Stotz, C. Cerda, C. MondacaSchachermayer, and K. Vera. 2013. Territorial user rights for artisanal fisheries in Chile-intended and unintended outcomes. Ocean and Coastal Management 71:284-295. https://doi. org/10.1016/j.ocecoaman.2012.09.015

Aburto, J., C. Gaymer, and G. Cundill. 2017. Towards local governance of marine resources and ecosystems on Easter Island. Aquatic Conservation: Marine and Freshwater Ecosystems 27:353-371. https://doi.org/10.1002/aqc.2665

Aburto, J., and W. Stotz. 2013. Learning about TURFs and natural variability: failure of surf clam management in Chile. Ocean and Coastal Management 71:88-98. https://doi. org/10.1016/i.ocecoaman.2012.10.013

Aburto, J. A., W. B. Stotz, and G. Cundill. 2014. Social-ecological collapse: TURF governance in the context of highly variable resources in Chile. Ecology and Society 19(1): 2. http://dx.doi. org/10.5751/ES-06145-190102

Adger, W. N. 2000. Social and ecological resilience: are they related? Progress in Human Geography 24:347-364. https://doi. org/10.1191/030913200701540465

Agapito, M., R. Chuenpagdee, R. Devillers, J. Gee, A. F. Johnson, and B. Trouillet. 2019. Beyond the basics: improving information about small-scale fisheries. Pages 377-395 in R. Chuenpagdee and S. Jentoft, editors. Transdisciplinarity for small-scale fisheries governance, Springer, Cham, Switzerland. https://doi. org/10.1007/978-3-319-94938-320

Arias, N., and W. Stotz. 2020. Sustainability analysis of the benthic fisheries managed in the TURF system in Chile. International Journal of the Commons 14(1): 344-365. http://doi. org/10.5334/ijc. 1011

Armitage, D., F. Berkes, A. Dale, E. Kocho-Schellenberg, and E. Patton. 2011. Co-management and the co-production of knowledge: learning to adapt in Canada's Arctic. Global Environmental Change 21:995-1004. https://doi.org/10.1016/j. gloenvcha.2011.04.006

Aswani, S. 2017. Customary management as TURFs: social challenges and opportunities. Bulletin of Marine Science 93(1): 3-12. https://doi.org/10.5343/bms.2015.1084

Berkes, F., J. Colding, and C. Folke. 2000. Rediscovery of traditional ecological knowledge as adaptive management. Ecological Applications 10:1251-1262. https://doi.org/10.2307/2641280

Boyd, E., and C. Folke. 2011. Adapting institutions: governance, complexity and social-ecological resilience. Cambridge University Press, New York, New York, USA. https://doi. org/10.1017/CBO9781139017237
Bundy, A., R. Chuenpagdee, S. Jentoft, and R. Mahon. 2008. If science is not the answer, what is? An alternative governance model for the world's fisheries. Frontiers in Ecology and the Environment 6:152-155. https://doi.org/10.1890/060112

Bundy, A., and A. Davis. 2012. Knowing in context: an exploration of the interface of marine harvesters' local ecological knowledge with ecosystem approaches to management. Marine Policy 38: 277-286. https://doi.org/10.1016/j.marpol.2012.06.003

Butler, J. R. A., A. Tawake, T. Skewes, L. Tawake and V. McGrath. 2012. Integrating traditional ecological knowledge and fisheries management in the torres strait, Australia: the catalytic role of turtles and dugong as cultural keystone species. Ecology and Society 17(4): 34. https://doi.org/10.5751/ES-05165-170434

Chambers, R. 1994. Participatory rural appraisal (PRA): analysis of experience. World Development. 22:1253-1268. https://doi. org/10.1016/0305-750X(94)90003-5

Chevalier, J., and D. Buckles. 2008. SAS2 A guide to collaborative inquiry and social engagement. Sage, International Development Research Centre, New Delhi, India. https://doi.org/10.4135/9789351507734

Cline, T. J., D. Schindler, and R. Hilborn, R. 2017. Fisheries portfolio diversification and turnover buffer Alaskan fishing communities from abrupt resource and market changes. Nature Communications 8(1): 14042. https://doi.org/10.1038/ncomms14042

Cundill, G., A. M. Leitch, L. Schultz, D. Armitage, and G. Peterson. 2015. Principle 5-encourage learning. Pages 174-192 in R. Biggs, M. Schluter, and M. Schoon, editors. Principles for building resilience: sustaining ecosystem services in socialecological systems. https://doi.org/10.1017/CBO9781316014240

Dakos, V., A. Quinlan, J. A. Baggio, E. Bennett, Ö. Bodin, and S. BurnSilver, S. 2015. Principle 2-manage connectivity. Pages 80-104 in R. Biggs, M. Schluter, and M. Schoon, editors. Principles for building resilience: sustaining ecosystem services in social-ecological systems. https://doi.org/10.1017/CBO9781316014240

Defeo, O., and A. Alava. 1995. Effects of human activities on long-term trends in sandy beach populations: the wedge clam Donax hanleyanus in Uruguay. Marine Ecology Progress Series 123:73-82. https://doi.org/10.3354/meps123073

Epstein, G., J. Pittman, S. M. Alexander, S. Berdej, T. Dyck, U. Kreitmair, K. Rathwell, S. Villamayor-Tomas, J. Vogt, and D. Armitage. 2015. Institutional fit and the sustainability of socialecological systems. Current Opinion in Environmental Sustainability 14:34-40. https://doi.org/10.1016/j.cosust.2015.03.005

Flores, E., and A. Mujica. 2009. Distribución y abundancia de larvas deEmerita analoga (Stimpson 1857) (Decapoda, Anomura) en la zona de Coquimbo y Caldera, Chile. Gayana (Concepción) 73(2):211-221. http://dx.doi.org/10.4067/S0717-65382009000200005

Gallardo, G. L., W. Stotz, J. Aburto, C. Mondaca, and K. Vera. 2011. Emerging commons within artisanal fisheries. The Chilean territorial use rights in fisheries (TURFs) within a broader coastal landscape. International Journal of the Commons 5:459-484. http://doi.org/10.18352/ijc.281 
Gelcich, S., T. P. Hughes, P. Olsson, C. Folke, O. Defeo, M. Fernández, S. Foale, L. H. Gunderson, C. Rodríguez-Sickert, M. Scheffer, R. S. Steneck, and J. C. Castilla. 2010. Navigating transformations in governance of Chilean marine coastal resources. Proceedings of the National Academy of Sciences 107 (39):16794-16799. https://doi.org/10.1073/pnas.1012021107

Gerhardinger, L. C., E. A. S. Godoy, and P. J. S. Jones. 2009. Local ecological knowledge and the management of marine protected areas in Brazil. Ocean and Coastal Management 52(3):154-165. https://doi.org/10.1016/j.ocecoaman.2008.12.007

Godet, M., and P. Durance. 2011. Strategic foresight for corporate and regional development. DUNOD, UNESCO, Fondation Prospective et Innovation, Paris, France.

González, J., C. Tapia, A. Wilson, J. Garrido, and M. Ávila. 2002. Estrategia de explotación sustentable de algas pardas en la zona norte de Chile. FIP N²00-19. Informe Final. Fondo de Investigación Pesquera, Valparaíso, Chile.

Grant, S., and F. Berkes. 2007. Fisher knowledge as expert system: a case from the longline fishery of Grenada, the Eastern Caribbean. Fisheries Research 84:162-170. https://doi.org/10.1016/ j.fishres.2006.10.012

Gutierrez, N. L., R. Hilborn, and O. Defeo. 2011. Leadership, social capital and incentives promote successful fisheries. Nature 470:386-389. https://doi.org/10.1038/nature09689

Janssen, M. A., J. M. Anderies, and E. Ostrom. 2007. Robustness of social-ecological systems to spatial and temporal variability. Society and Natural Resources 20:307-322. https://doi. org/10.1080/08941920601161320

Lipsman, J. 2019. Local knowledge and democracy in fisheries management: a case study of adaptation to the Anthropocene in southeast Louisiana. Ecology and Society 24(4): 20. https://doi. org/10.5751/ES-11100-240420

Kalikoski, D. C., M. Vasconcellos, and L. Lavkulich. 2002. Fitting institutions to ecosystems: the case of artisanal fisheries management in the estuary of Patos Lagoon. Marine Policy 26:179-196. https://doi.org/10.1016/S0308-597X(01)00048-3

Masterson, V. A., R. C. Stedman, J. Enqvist, M. Tengö, M. Giusti, D. Wahl, and U. Svedin. 2017. The contribution of sense of place to social-ecological systems research: a review and research agenda. Ecology and Society 22(1): 49. https://doi.org/10.5751/ ES-08872-220149

McLachlan, A., J. Dugan, O. Defeo, A. Ansell, D. Hubbard, E. Jaramillo, and P. Penchaszadeh. 1996. Beach clam fisheries. Oceanography and Marine Biology 34:163-232.

Moraga, J., E. Valdebenito, and J. Rutllant. 2001. Condiciones oceanográficas durante la fase de relajación de un evento de surgencia invernal frente a Punta Lengua de Vaca, Coquimbo. Investigaciones marinas 29:59-71. http://dx.doi.org/10.4067/ $\underline{\text { S0717-71782001000100006 }}$

Mujica, A., M. L. Nava, and A. Vargas. 2014. Dispersion of Emerita analoga (Stimpson, 1857) larvae in northern coast of Chile $\left(25^{\circ}-31.5^{\circ} \mathrm{S}\right)$. Latin American Journal of Aquatic Research 42(3):418-426.
Ojea, E., I.Pearlman, S. D. Gaines, and S. E. Lester, S. E. 2017. Fisheries regulatory regimes and resilience to climate change. Ambio 46(4), 399-412. https://doi.org/10.1007/s13280-016-0850-1

Olivares, G. 2005. The role of semi-enclosed embayments for the metapopulation dynamics of coastal marine invertebrates in the Humboldt Current System. Dissertation. University of Bremen, Bremen, Germany.

Ortega, L., J. C. Castilla, M. Espino, C. Yamashiro, and O. Defeo. 2012. Effects of fishing, market price, and climate on two South American clam species. Marine Ecology Progress Series 469:71-85. https://doi.org/10.3354/meps10016

Ostrom, E. 1990. Governing the commons: the evolution of institutions for collective action. Cambridge University Press, New York, New York, USA. https://doi.org/10.1017/ CBO9780511807763

Ostrom, E. 2009. A general framework for analyzing sustainability of social-ecological systems. Science 325 (5939):419-422. https://doi.org/10.1126/science.1172133

Pomeroy, R. S., B. M. Katon, and I. Harkes. 2001. Conditions affecting the success of fisheries co-management: lessons from Asia. Marine Policy 25:197-208. https://doi.org/10.1016/ $\underline{\text { S0308-597X(01)00010-0 }}$

Riascos, J. M., D. Carstensen, J. Laudien, W. E. Arntz, M. E. Oliva, A. Guntner, and O. Heilmayer. 2009. Thriving and declining: climate variability shaping life-history and population persistence of Mesodesma donacium in the Humboldt Upwelling System. Marine Ecology Progress Series 385:151-163. https://doi. org/10.3354/meps08042

San Martín, G., A.M. Parma, J. M. L. Orensanz. 2010. The Chilean experience with territorial use rights in fisheries. Pages 324-337 in R. Q. Grafton, R. Hilborn, D. Squires, M. Tait, and M. Williams, editors. Handbook of marine fisheries conservation and management. Oxford University Press, Inc., New York, New York, USA.

Servicio Nacional de Pesca y Acuicultura (SERNAPESCA). 2018. Anuario estadístico de pesca. SERNAPESCA, Valparaíso, Chile. [online] URL: http://www.sernapesca.cl/informacionutilidad/anuarios-estadisticos-de-pesca-y-acuicultura

Silvano, R. A. M., and J. Valbo-Jørgensen. 2008. Beyond fishermen's tales: contributions of fishers' local ecological knowledge to fish ecology and fisheries management. Environment. Development and Sustainability 10:657-675. https://doi.org/10.1007/s10668-008-9149-0

Tapia, C., J. González, A. Wilson, J. Garrido, and J. Orensanz. 2002. Ordenación espacio temporal de la actividad extractiva artesanal entre la I y IV regiones. Informe Final. FIP Nº2001-25. Fondo de Investigación Pesquera, Valparaíso, Chile.

Tengö, M., E. Brondizio, T. Elmqvist, P. Malmer, and M. Spierenburg. 2014. Connecting diverse knowledge systems for enhanced ecosystem governance: the multiple evidence base approach. Ambio 43:579-591. https://doi.org/10.1007/s13280-014-0501-3

Tengö, M., R. Hill, P. Malmer, C. M. Raymond, M. Spierenburg, F. Danielsen, T. Elmqvist, and C. Folke. 2017. Weaving knowledge 
systems in IPBES, CBD and beyond-lessons learned for sustainability. Current Opinion in Environmental Sustainability 26-27:17-25. https://doi.org/10.1016/j.cosust.2016.12.005

Tesfamichael, D., T. J. Pitcher, and D. Pauly. 2014. Assessing changes in fisheries using fishers' knowledge to generate long time series of catch rates: a case study from the Red Sea. Ecology and Society 19(1): 18. http://dx.doi.org/10.5751/ES-06151-190118

Thiel, M., E. Macaya, E. Acuna, W. Arntz, H. Bastias, K. Brokordt, P. Camus, J. Castilla, L. Castro, M. Cortes, C. Dumont, R. Escribano, M. Fernandez, J. Gajardo, C. Gaymer, I. Gomez, A. Gonzalez, H. Gonzalez, P. Haye, J. Illanes, J. Iriarte, D. Lancellotti, G. Luna-Jorquera, C. Luxoroi, P. Manriquez, V. Marin, P. Munoz, S. Navarrete, E. Perez, E. Poulin, J. Sellanes, H. Sepulveda, W. Stotz, F. Tala, A. Thomas, C. Vargas, J. Vasquez, and J. Vega. 2007. The Humboldt Current System of northern and central Chile: oceanographic processes, ecological interactions and socioeconomic feedback. Oceanography and Marine Biology 45:195-344.

Valle-Levinson, A., and J. Moraga-Opazo. 2006. Observations of bipolar residual circulation in two equatorward-facing semiarid bays. Continental Shelf Research 26:179-193. https://doi. org/10.1016/j.csr.2005.10.002 